\title{
Entrepreneurship Development in Nigeria: A Review
}

\author{
Idam, Linus Egwu, Phd, Fnim \\ Adjunct Senior Lecturer Department Of Accountancy/Business Administration And Entrepreneurial Studies, \\ Faculty Of Humanities And Social Sciences, Federal University, Ndufu-Alike Ikwo, Nigeria
}

\begin{abstract}
Empirical researchers and policy makers have shown increasing interest in entrepreneurship and its association with economic development. In the literature, a good number of studies have established positive relationship between entrepreneurship and employment generation, poverty alleviation and economic development. It is for this reason that various governments in Nigeria over the past three decades implemented a number of policies and programmes aimed at addressing the high rate of unemployment, wide-spread poverty and low level of economic development. Unfortunately, the various policies and programmes have failed to achieve the desired results. This paper attempts to identify the causal factors that militate against the effectiveness of government efforts at entrepreneurship development. Major government programmes are examined to identify inherent weaknesses. Supported by empirical and theoretical literature, this paper asserts that the treatment of all small businesses as entrepreneurial constrains the development of entrepreneurship in Nigeria and in other developing economies, as policies and programmes are implemented across the board. It canvasses a distinctive categorization to distinguish entrepreneurial firms from non-entrepreneurial small businesses and the development and implementation of policies and strategies that are suitable for each class of small businesses. While all small businesses need support, entrepreneurial firms need higher level of support to enable them play their catalytic role in employment generation and economic development. Other group of challenges identified by empirical studies, which militate against the development of small businesses, entrepreneurial and non-entrepreneurial, should be properly addressed. These include environmental hazards, infrastructural inadequacies, high level of insecurity and the incidence of wide-spread corruption.
\end{abstract}

Key words: Entrepreneurship development; Entrepreneurial firms; Small businesses.

\section{Introduction}

Entrepreneurship, as an emerging field of study and as an area of human endeavour, has received increasing interest of researchers, academicians and policy makers the world over. It has equally provoked controversies over its concept and definition. Entrepreneurship is seen as an effective means not only of combating unemployment, poverty and under-development in the developing nations, but also as a strategy for rapid economic development in both developed and developing nations (Schumpeter, 1934; Harper, 1991; Morris \& Lewis, 1991; Hamilton, 2000; Clausen, 2006; Praag \& Versloot, 2007).

Naude (2011) contends that global development is entering a phase, where entrepreneurship will increasingly play a more important role. He adduces three reasons for this development. The first is that the managed economy of the 1970s - 2000 in the West, characterized by reliance on big business and mass production, has given way to a so-called entrepreneurial economy, where knowledge-driven goods and services are more flexibly provided by smaller creative class. Secondly, impressive growth in the emerging economies, notably Brazil, Russia, India and China, has been driven by innovative entrepreneurial revolution. Thirdly, in the least developed countries, where dependency is high, donor agencies have been shifting emphasis in development cooperation towards private sector development. Naude (2011) draws the conclusion that entrepreneurship will contribute to growth and employment creation in advanced, emerging and least developed economies alike.

In Nigeria, studies have been carried out on the effect of entrepreneurship development on the problem of high unemployment rate, high level of poverty and slow economic growth rate (Adejumo, 2001; Ariyo, 2005; Agboli \& Ukaegbu, 2006; Abimbola \& Agboola, 2011; Thaddeus, 2012; Oyelola et al., 2013; Salami, 2013). Given the generally held view that entrepreneurship development is the key to poverty eradication, employment generation and rapid economic development, various governments in Nigeria have, over the past three decades, evolved policies and programmes, aimed at developing entrepreneurship through the development of small and medium scale enterprises (SMEs). In spite of all the efforts, unemployment rate has remained high, rising from $13.1 \%$ in year 2000 to $23.9 \%$ in 2011, with youth unemployment put at over 50\% (IMF, 2013; Risenetworks, 2013). Over 100 million Nigerians live below poverty line on less than US $\$ 1$ a day and with the percentage of the population in abject poverty rising from $54.7 \%$ in 2004 to $60.9 \%$ in 2010 (Yusuf, 2011). Above all, Nigeria's human development index (HDI) remains abysmally low at 0.453 , much below world weighted average of 0.7 (UNDP, 2006). 
The questions that this situation raises are: Why have all efforts to develop entrepreneurship in Nigeria failed to yield the desired results? Could it be that the approach and strategies used are flawed? This is the problem that this paper attempts to address. In the next section, conceptual perspectives will be discussed in review of relevant theories and concepts of entrepreneurship reported in the literature, followed by an examination of selected government policies and programmes designed to develop entrepreneurship in Nigeria. This is followed by a discussion of issues raised in the conceptual review and in the government programmes highlighted, with a closing section on conclusion and recommendations.

\section{Conceptual Perspectives}

Following increasing interest of empirical researchers and academic theorists in the field of entrepreneurship, various definitions and concepts are found in the literature. A common denominator in a good number of studies is the important role of three key factors namely, risk- taking, innovation and identification and use of opportunities, with varying degrees of emphasis (Rusu, Isac, Cureteanu \& Scorba, 2012). Schumpeter (1934), a development economist, sees entrepreneurship from the point of view of value creation and defines an entrepreneur as a risk-taking innovator needed for rapid economic development, through the process of "creative destruction", by which obsolete technologies and ideas are replaced by new ones. Schumpeter $(1934,1942)$ argues that entrepreneurship has the potential for economic development, through the introduction of new innovative combinations, which render old industries obsolete. According to Joseph Schumpeter, the carrying out of new combinations can take several forms including 1) the introduction of a new product, 2) the introduction of a new mode of production, 3) the opening up of a new market and 4) the reorganization of an existing firm to respond to changing technology.

While Schumpeter $(1934,1942)$ sees the entrepreneur as an agent of change, who moves the market away from equilibrium, Drucker (1985) contends that the entrepreneur is not necessarily an agent of change, but one that searches for change, responds to it and exploits it as an opportunity. He agrees with Knight (1921) who asserts that entrepreneurs attempt to predict and act upon change, bearing the uncertainty of market dynamics. Stevenson and Jarillo (1990) define entrepreneurship as a process by which individuals, either on their own, or within organization, pursue opportunities. Shane and Venkataraman (2000) similarly express the strong view that the existence, nature and discovery of opportunities constitute the real core of entrepreneurship. They provide explanation why some people discover these opportunities while others do not.

Leibenstein (1968) explains that entrepreneurship involves activities that are necessary to create or carry on an enterprise, while Gartner (1988) simply defines entrepreneurship as creation of new organizations. Martin and Osberg (2007) assert that entrepreneurship is the product of a combination of three elements: the context in which the opportunity arises or is created, a set of personal competences necessary to identify and use the opportunity and the capacity to actualize the opportunity by transforming it into business. Baron and Henry (2010) argue that entrepreneurs not only identify, but also create opportunities, because their actions produce effects, which in turn, produce opportunities that did not previously exist.

A number of empirical studies have confirmed the close association of environmental factors and the development of entrepreneurship (Wilken, 1979; Thornton, 1999; Lee \& Peterson, 2000; Agboli \& Ukaegbu, 2006; Abimbola \& Agboola, 2011). Thornton (1999) makes a distinction between the role of individuals with identifiable entrepreneurial traits and characteristics, classified as supply-side perspective and the role of culture and environment (demand perspective) in the development of entrepreneurship. Wilken (1979) emphasizes the importance of government policies and programmes in the creation of conducive socio-economic environment required for the growth of entrepreneurship.

Alvarez and Busenitz (2001) propose a resource-based theory of entrepreneurship, which states that access to resources is an important predictor of opportunity-based entrepreneurs. To Alvarez and Busenitz (2001), resources include ability to identify opportunities and opportunity-seeking behaviour, as well as the process of organizing and combining the required resources for productive purpose. Davidson and Honing (2003) aver that access to resources will likely enhance individual's ability to detect and exploit opportunity. Using a survey data from Global Entrepreneurship Monitor (GEM) in 2001 (GEM, 2005), Clausen (2006) investigated the extent to which individual differences in resources are related to nascent entrepreneurship. His findings show that individuals with high general and specific human capital as well as entrepreneurship capital are significantly more likely to be engaged in entrepreneurial behaviour. Human capital is broken down into education, skill and experience (Anderson \& Miller, 2003; Clausen, 2006).

The relationship between financial resources and entrepreneurship development has however become controversial in recent times. While some empirical studies in the literature show positive relationship between personal wealth and entrepreneurship, given financial constraints (Evans \& Jovanovic, 1989; Evans \& Leighton, 1989; Holtz-Eakin, Joulfaian \& Rosen, 1994; Fonseca, Lopez-Garcia \& Pissaride, 2001; Fonseca, Michaud \& Sopraseuth, 2007), others found no significant relationship between individual wealth and propensity to become an entrepreneur, particularly in developed economies (Hurst \& Lusardi, 2004). Nanda (2009), using data from 
Denmark reports similar findings as Hurst and Lusardi (2004) found for the United States, that there is nonlinear relationship between personal wealth and entrepreneurship, except in the top 5\% of wealth distribution, where the propensity to start a new business rises sharply.

From the empirical studies, it is apparent that the non-significant relationship between financial resources and entrepreneurship relates to advanced economies (U.S. and Denmark), where there is no pronounced credit constraints. In the developing economies like Nigeria, where there are wide-spread financial constraints, particularly for potential and nascent entrepreneurs, a strong positive relationship exists between access to financial resources and entrepreneurial process (Akanji, 2001; Central Bank of Nigeria, 2011). This confirms the finding of Evans and Jovanovic (1989) and others with similar findings.

In entrepreneurship literature, entrepreneurs are generally defined as small- scale business owners. Policy makers in many economies, including Nigeria, similarly treat all small-scale businesses as entrepreneurial. This paper canvasses a distinctive definition of entrepreneurship, to separate entrepreneurial firms from non-entrepreneurial small businesses. The position is supported by Lugar and Koo (2005), who contend that not all small firms are entrepreneurial and not all self-employed persons are entrepreneurs. Self employment, Lugar and Koo (2005) assert, is often not associated with the creation of firms, whereas entrepreneurship is. This view is supported by Praag and Versloot (2007). Earle and Sakova (2000) aver that self- employment, a traditional indicator of entrepreneurship, in many cases, may be a disguise for unemployment.

Carland et al (1984), in conceptualizing the differentiation of entrepreneurs from small business owners, proposed criteria for identifying entrepreneurial firms, namely, that such a firm must satisfy at least one of the four conditions listed by Schumpeter (1934) that reflect entrepreneurial behaviour. These are (1) the introduction of new products, (2) the introduction of new mode of production, (3) the opening up of new market and (4) the reorganization of an existing firm to respond to changing technology.

Entrepreneurship, in the literature, is classified into opportunity-based and necessity-based categories, depending on whether the entrepreneurship is driven by the discovery and exploitation of opportunity or it is prompted by unemployment, or need for survival (Global Entrepreneurship Monitor, 2012). Reynolds (2000) and Clausen (2006) classify necessity-driven entrepreneurship as disguised unemployment, which indicates that the individual's resources and competences are misallocated and put into less productive use and therefore less productive to the society. This paper contends that self employment and necessity-based entrepreneurship should not form the bases for identifying entrepreneurial firms. Out of necessity, a potential entrepreneur may go searching for opportunity (Druker, 1985), or his activity may produce effects, which in turn produce opportunities that did not previously exist (Baron \& Henry, 2010). Some necessity-driven individuals may thus emerge as opportunity-driven entrepreneurs with ascribed characteristics.

In the light of the above, this paper conceptualizes entrepreneurship as the act of identifying and exploiting opportunities, through innovative process, under condition of uncertainty, to either create new business, or reorganize existing one capable of generating employment for others and value for stakeholders. To be classified as entrepreneurial firm, a business must at least show potentials for growth through introduction of new product, new production process, or new marketing strategies. By this operational definition, entrepreneurial firms will be identified and separated from other small non-entrepreneurial businesses. In the next section, selected entrepreneurship development programmes in Nigeria will be evaluated to identify weaknesses that have constrained their effectiveness.

\section{Selected Entrepreneurship Development Programmes In Nigeria}

Nigerian governments, particularly since the structural adjustment programme of mid 1980s, have put in place policies and programmes aimed at entrepreneurship development, as a means of employment generation, poverty alleviation and rapid economic development. The major programmes are examined below:

i. Small and Medium Industries Equity Investment Scheme (SMIEIS): In reaction to the Federal Government concern for the promotion of small and medium enterprises, the Bankers Committee, in December, 1999, approved the setting up of the scheme under which all banks in Nigeria are required to set aside $10 \%$ of their profit after tax for investment in small and medium enterprises (Central Bank of Nigeria, 2003). The scheme has not attracted the expected patronage by the target group, as evidenced in the relatively low drawdown and large pool of investible funds (Central Bank of Nigeria, 2003). A major problem is lack of national spread in utilization. In 2009, only N28 billion (or 67\%) of the N42 billion set aside under the scheme was invested, out of which, Lagos State took $41.25 \%$, while 24 states of the federation each had less than $1 \%$, with 12 states recording nil investment (Central Bank of Nigeria, 2009).

ii. Bank of Industry (BOI): Established by the Federal Government of Nigeria in 2000 by a merger of Nigerian Industrial Development Bank (NIDB), the Nigerian Bank for Commerce and Industry (NBCI) and National Economic Reconstruction Fund (NERFUND), BOI combines the functions originally performed by the three merged institutions (Central Bank of Nigeria, 2001). Although NERFUND was specifically established to 
provide medium and long term credit to small and medium scale enterprises, the Bank of Industry, being urban based, appears to focus on big industrial establishments to the detriment of small enterprises.

iii. Nigerian Agricultural Cooperative Rural Development Bank (NACRDB): Three Federal Government development finance institutions namely, The Nigerian Agricultural Cooperative Bank (NACB), Peoples Bank and Family Economic Advancement programme (FEAP) were merged in 2000 to form NACRDB, which took off in 2001 with authorised capital of N1 billion (Central Bank of Nigeria, 2001). The three merged institutions were rural based, with similar functions of providing easy-to-access credit facilities and agricultural inputs to rural farmers, cooperative societies and small businesses. The problem is that the bank has limited reach and over $80 \%$ of the target population have no access to the services of the institution.

iv. Microfinance Bank: The Central Bank of Nigeria launched the Microfinance Policy, Regulatory and Supervisory Framework for Nigeria in 2005 and revised same in 2011. The Framework, which provided for the transformation of former community banks to unit microfinance banks on meeting specified requirements, aimed at solving the problem of urban bias and provision of affordable financial services to small scale businesses and active poor, to create employment opportunities, increase their productivity and uplift their standard of living (Central Bank of Nigeria, 2011). However, the problem of urban bias has not been effectively addressed and a large segment of target small businesses and active poor in the rural areas have no access to microfinance services.

v. The National Directorate of Employment (NDE): Legally empowered by NDE Act, CAP 250 of the Law of the Federal Republic of Nigeria (formally Decree No 34 of 1989, the Directorate has responsibility to design, and implement programmes to combat mass unemployment in Nigeria. Its programmes include vocational skills acquisition training, employment counselling and job linkages, entrepreneurial training and enterprise creation, amongst others. The major weakness is the inability of the Directorate to provide post training resources for job creation, resulting from lack of commitment by various levels of government.

vi. Small and Medium Enterprises Development Agency of Nigeria (SMEDAN): Established by Small and Medium Enterprises Development Agency Act of 2003, the Agency has the mandate to stimulate, monitor, and coordinate the development of micro, small and medium enterprises (MSMEs) in Nigeria, by initiating and articulating policies, programmes, instruments and support services for the development of MSMEs subsector. So far, SMEDAN has not made any significant impact on the target population, as a result of lack of awareness. vii. Establishment of Entrepreneurship Development Centres (EDCs): In a bid to provide institutional support for the development of entrepreneurship, the National Entrepreneurship Development Centre was established. Additionally, entrepreneurship development centres have been established in Nigeria's tertiary institutions and entrepreneurship has become a compulsory course of study in Nigerian universities. However, the effectiveness of such academic programmes is constrained by a disconnect between the centres and the industrial sector that should provide practical training and experience for the students.

viii. Youth Enterprise with Innovation in Nigeria (YouWIN): This is one of the latest initiatives of the Federal Government of Nigeria, aimed at developing entrepreneurship in the country. It is defined as an innovative business plan competition aimed at job creation by encouraging and supporting aspiring entrepreneurial youths in Nigeria to develop and execute business ideas (YouWIN, 2013). Youths between ages 18 to 45 years compete for award of N1 million to N10 million to execute their business ideas. The first competition was held in 2011, with 1200 successful businesses. The second involved only women; while the third will feature both men and women entrepreneurs in Nigeria within the age bracket (YouWIN, 2013). This is the first time effort is made to identify entrepreneurial firms, but the sustainability is in doubt because of the nature of the award and the political undertone.

\section{Discussion}

From the various programmes outlined above, it can be unequivocally stated that governments in Nigeria have persistently made effort towards the development of entrepreneurship in the country. It is, however, a matter of concern that, in spite of these efforts, the expected results in terms of solving the problem of massive unemployment, high poverty rate and low rate of economic development, have remained elusive. Two major problems are identifiable.

The first problem is that the approach to entrepreneurship development in Nigeria has remained faulty. This paper argues that the treatment of all small business owners as entrepreneurs constrains the development of entrepreneurship in Nigeria, as in other developing countries. Government policies and programmes focus generally on the development of small and medium scale enterprises and no effort is made, until recently, to distinguish entrepreneurial firms from non-entrepreneurial small businesses, as canvassed by Garland et al. (1984), Earle and Sakova (2000), Lugar and Koo (2005) and Praag and Versloot (2007).

While the development of all small businesses is important for socio-economic growth of an economy, the distinctive role of entrepreneurs in creation of jobs for others and in accelerated economic development has to be clearly identified. Small non-entrepreneurial businesses need to be encouraged and supported to keep the 
youths usefully engaged in self employment and thus solve the problem of youth restiveness and indulgence in criminal activities. Economic benefits are equally derivable as the self employed becomes economically self sufficient and provides for the immediate family.

Policies and programmes put in place to grow small businesses remain beneficial to the economy, but classification of small businesses into entrepreneurial and non entrepreneurial firms will allow for specific strategies for each group. While small non-entrepreneurial businesses may need basic skills training, soft loans and grants to be fully self employed, entrepreneurs, in order to play their catalytic role in economic development, need higher level of support in terms of research and development, as well as the provision of grants and venture capital for the execution of business plans. The recently introduced Youth Enterprise with Innovation in Nigeria programme appears to be a right step in the right direction. However the sustainability of the programme is in doubt, given the political undertone and the faddish nature. To be sustainable, the programme should be built into existing institutions.

The second set of problems that constrain the development of entrepreneurship in Nigeria relate to environmental, socio-economic, political and cultural factors that affect both entrepreneurial firms and nonentrepreneurial small businesses (Agboli \& Ukaegbu, 2006; Eneh, 2010; Abimbola \& Agboola, 2011; Oyelola et al.,2013). Agboli and Ukaegbu (2006) emphasize the devastating effect of poor infrastructural facilities, including epileptic power supply, poor condition of road network and inadequate water supply, on emerging businesses. A related environmental factor is the incessant cases of kidnapping and the insurgence of 'Boko Haram'sect, which create unhealthy and insecure environment for business operation. Abimbola and Agboola (2011), quoting World Bank Doing Business 2008 report, showed Nigeria as ranking 108 out of 178 economies compared in terms of business environment friendliness, with many Sub Saharan countries including Ghana, Mauritius, Botswana, Ethiopia, South Africa and Kenya, having higher rating.

The high cost of doing business in Nigeria imposes economic dimension of challenges encountered by nascent enterprises. The weight of high incorporation costs, legal and professional fees, business permits and licences add up to other start-up costs to create heavy burden on small businesses faced with limited access to credit facilities and high interest rates. The incidence of multiple taxation and levies in different forms at federal, state and local government levels constitute militating forces for emerging small businesses, whether entrepreneurial or not.

Above all, corruption, in all its ramifications, has continued to pose serious threat to the survival of small businesses in Nigeria. Transparency International's 2010 Corruption Perception Index places Nigeria $134^{\text {th }}$ out of 178 surveyed economies. This translates to a score of 2.4 out of 10 points or 24\% (Economy Watch, 2010). Corrupt practices appear to permeate all levels of our public life, from high ranking officers, who collect material inducement to disburse government approved funds to micro, small and medium scale enterprises, down to office assistants, who declare files missing if not submitted with tips.

\section{Conclusion And Recommendations}

Efforts made by various governments in Nigeria over the years to develop entrepreneurship have not yielded the desired results. One major reason is the treatment of all small businesses as entrepreneurial firms and implementation of policies and programmes across the board. The second set of problems relate to economic, social and political factors that create hostile environment inimical to the development of entrepreneurial firms and other small businesses.

To address these challenges and facilitate the development of entrepreneurship in Nigeria, the following measures are recommended:

Entrepreneurial firms should be separated from other non entrepreneurial small businesses, to allow for distinct policies and programmes required by each category of small businesses. To achieve this categorization, all small businesses should be encouraged to submit their business plans to a development agency such as the Small and Medium Enterprises Development Agency of Nigeria (SMEDAN). From the business plans, potential and nascent entrepreneurs are identified and separately registered. The Agency should develop a strategy for monitoring, on yearly basis, firms that are classified as entrepreneurial for at least a period of three years. Firms that fail to realize projections in their business plans should be declassified. Entrepreneurial firms should be given higher level of support including outright government grants and soft loans for research and development and easy access to venture capitalists and business angels. The development of other small businesses will continue to be pursued to promote self employment, reduce crime rate and improve the people's living condition. To this end, the implementation of the Microfinance Policy should be reviewed for greater impact on the generality of the rural populace.

Finally, government should strive to reduce the cost of doing business in Nigeria, to the benefit of both entrepreneurial firms and other small businesses, by providing conducive environment. To achieve this objective, infrastructural facilities, including good road network, stable power and water supply should be 
provided as a matter of priority. Security should be beefed up in both urban and rural communities and the problem of corruption should be realistically addressed.

\section{References}

[1]. Abimbola, O. H. \& Agboola, G. M. (2011). Environmental factors and entrepreneurship development in Nigeria. Journal of Sustainable Development in Africa, 13(4), 166-176. Retrieved from www-jsd-africa.com.

[2]. Adejumo, G. (2001). Indigenous entrepreneurship development in Nigeria: Characteristics, problems and prospects. Advances in Management: Journal of Department of Business Administration, University of Ilorin, Nigeria, 2(1),112-122.

[3]. Agboli, M. \& Ukaegbu, C. C. (2006). Business environment and entrepreneurial activity in Nigeria: Implications for industrial development. Journal of Modern African Studies. 44(1), 1-30.

[4]. Akanji, O. O. (2001). Microfinance as strategy for poverty reduction. Central Bank of Nigeria Economic and Financial Review, 39(4), 111-134.

[5]. Alvarez, S. A. \& Busenitz, L. W. (2001). The entrepreneurship of resource-based theory. Journal of Management, 27, 755-775.

[6]. Anderson, A. \& Miller, C. (2003). Class matters: Human and social capital in the entrepreneurial process. Journal of Social Economics, 32, 17-36.

[7]. Ariyo, D. (2005). Small firms are the backbone of Nigerian economy. Retrieved from http://www. africaeconomicanalysis.org

[8]. Baron, R. A. \& Henry, R. A. (2010). How entrepreneurs acquire the capacity to excel: Insights from research on expert performance. Strategic Entrepreneurship Journal 4(1), 49-65.

[9]. Berglann, H., Moen, E., Roed, K. \& Skogstrom, J. F. (2009). Entrepreneurship:Origins and returns. IZA Discussion Paper No. 4250. Retrieved from http:/iza.org/dp4250pdf.

[10]. Carland, J. W., Hoy, F., Boulton, W. R., et al. (1984). Differentiating entrepreneurs from small business owners: A conceptualization. Academy of Management Review, 9(2), 354-359.

[11]. Central Bank of Nigeria (2001). Banking Supervision Annual Report. CBN, Abuja, Nigeria. Author.

[12]. Central Bank of Nigeria (2003). The small and medium industries equity investment scheme. Central Bank of Nigeria Brief Serial No. 2002-3/09, 65-69, CBN, Abuja, Nigeria. Author.

[13]. Central Bank of Nigeria (2009). Geographical distribution of small and medium industries equity investment scheme. Retrieved from www.cenbank.org/out/publications/reports/DFD/2009/

[14]. Central Bank of Nigeria (2011, April 29). Revised Microfinance Framework for Nigeria. Retrieved from http:/www.cbn.gov.ng/out/2011/pressrelease/gvd/ revised\%20Microfinance\%20Policy\%20July\%2011.

[15]. Clausen, T. H. (2006). Who identifies and exploits entrepreneurial opportunities? Centre for Technology, Innovation and Culture, University of Oslo. Retrieved from www.ccsr.ac.uk/method/festival/.../paperTommyClausenpdf.

[16]. Davidson, P. \& Honing, B. (2003). The role of social and human capital among nascent entrepreneurs. Journal of Business Venturing, 18, 301-331.

[17]. Drucker, P. F. (1985). Innovation and entrepreneurship: Practice and Principles.New York, NY: Harper Business.

[18]. Earle, J. S. \& Sakova, S. (2000). Business start-ups or disguised unemployment? Evidence on the character of self -employment from transition economies. Labour Economics, 7, 575-601.

[19]. Economy Watch (2010). Corruption perception index and score for year 2010.Retrieved from www.economywatch.com/economic-statistics/

[20]. Eneh, O. C. (2010). Survival strategies for entrepreneurs in dwindling Nigerian economy. Asian journal of Industrial Engineering, 2, 52-62. Retrieved from scialert.net/fulltext/?doi=ajie.2010.52.62\&org=12.

[21]. Evans, D. S. \& Jovanovic, B. (1989). An estimated model of entrepreneurial choice under liquidity constraints. Journal of Political Economy, 97(4), 808-827.

[22]. Evans, S. \& Leighton, L. (1989). Some empirical aspects of entrepreneurship. American Economic Review, 79(3), 519-535.

[23]. Fonseca, R., Lopez-Garcia, P. \& Pissarides, C. A. (2001). Entrepreneurship, start-up costs and employment. European Economic Review, 45, 692-705.

[24]. Fonseca, R., Michaud, P. C. \& Sopraseuth, T. (2007). Entrepreneurship, wealth, liquidity constraints and start-up costs. IZA Discussion Paper No.2874. Retrieved from http:/ftp.iza.org/dp2874.pdf.

[25]. Gartner, W. B. (1988). Who is an entrepreneur? is the wrong question. Entrepreneurship, Theory and Practice, 13(4), 47-68.

[26]. Global Entrepreneurship Monitor (2012). Global entrepreneurship report. Retrieved from www.gemconsortium.org/doc/download/2645

[27]. Hamilton, B. H. (2000). Does entrepreneurship pay? An empirical analysis of the returns to self-employment. Journal of Political Economy, 108(3), 601-631.

[28]. Harper, M. (1991). The role of enterprise in poor countries. Entrepreneurship, Theory and Practice, 15(4), 7-11.

[29]. Holtz-Eakin, D., Joulfaian, D. \& Hosen, H. S. (1994). Sticking it out: Entrepreneurial survival and liquidity constraints. Journal of Political Economy, 102(1). Retrieved from www.jstor.org/stable/2138793.

[30]. Hurst, E. \& Lusardi, A. (2004). Liquidity constraints, household wealth and entrepreneurship. Journal of Political Economy, $112(2), 319-347$.

[31]. IMF (2013). World economic outlook report. Retrieved from world-economic-outlookfindthedata.org/1/4135/Nigeria

[32]. Klyver, K. \& Thorton, P. H. (2010). The cultural embeddedness of entrepreneurial self-efficacy and intentions: A cross-national comparison. Retrieved from workspace.imperial.ac.uk/.../THORNTON\%20.

[33]. Knight, F. (1921). Risk, uncertainty and profit. Buston, MA: Houghton Mifflin.

[34]. Lee, S.M. \& Peterson, S. J. (2000). Culture, entrepreneurship orientation and global competitiveness. Journal of World Business, 35(4), 401-416. Retrieved from http://dx.doi.org/10.1016/S1090-9516(00)00045-6

[35]. Leibenstein, H. (1968). Branch of economics is missing - micro-micro- theory. Journal of Economic Literature, 17, 477-502.

[36]. Lugar, M. I. \& Koo, J. (2005). Defining and tracking business start-ups. Small Business Economics, 24(1), 17-28. Retrieved from www.jstor.org/stable/40229406

[37]. Martin, R. \& Osberg, S. (2007). Social entrepreneurship: The case for definition. Standford Social Innovation Review. Retrieved from www.ssireview.org

[38]. Morris, M. H. \& Lewis, P. S. (1991), Entrepreneurship as a significant factor in social quality of life. Journal of Business Research, 23(1), 21-36.

[39]. Nanda, R. (2009). Entrepreneurship and the discipline of external finance. Harvard Business School Working Paper 08-047. Retrieved from www.hbs.edu/faculty/Publication\%20Files/11-098.pdf 
[40]. Naude, W. (2011). Entrepreneurship and economic development. United Nations University. Retrieved from http://unu.edupublications-WIDER Angel-Article.

[41]. Oyelola, O. T., Ajiboshin, I, O., Raimi, L., Raheem, S. \& Igwe, C. N. (2013). Entrepreneurship for sustainable economic growth in Nigeria. Journal of Sustainable Development Studies. 2(2), 197-215. Retrieved from

[42]. www.worldsustainable.org/index.php/

[43]. Praag, C. M. V. \& Versloot, P. H. (2007). What is the value of entrepreneurship? IZA Discussion Paper No. 3014. Retrieved from ftp.iza.org/dp3014pdf

[44]. Reynolds, P. D. (2000). National panel study of U.S. business start-ups. Background and methodology. Retrieved from http://projects.isr.umich.edu/PSED/

[45]. Risenetworks (2013). Youth unemployment in Nigeria: Shocking statistics, facts and why the future may not be so bright after all. Retrieved from http://risenetworks.org/2013/05/16/

[46]. Rusu, S., Isac, F., Cureteanu, R. \& Csorba, L. (2012 March). Entrepreneurship and entrepreneurs: A review of literature concepts. African Journal of Business Management, 6(10), 3570-3575. DOI: 10.5897/AJBM11.2785.

[47]. Salami, C. G. E. (2013 July). Youth unemployment in Nigeria: A time for creative intervention. International Journal of Business and Marketing Management, 1(2), 18-26. Retrieved from www.resjournal.org/IJBMM/pdf

[48]. Schumpeter, J. A. (1934). The theory of economic development. Cambridge, MA: Harvard University Press.

[49]. Schumpeter, J. A. (1942). Capitalism, socialism and democracy. New York, NY:Harper.

[50]. Shane, S. A. \& Venkataraman, S. (2000). The promise of entrepreneurship as a field of research. Academy of Management Review, 25, 217-226.

[51]. Stevenson, H. H. \& Jarillo, J. C. (1990). A paradigm of entrepreneurship research: Entrepreneurial management. Strategic Management Journal, 11, 17-27.

[52]. Thaddeus, E. (2012). Perspectives: Entrepreneurship development and growth of enterprises in Nigeria. Entrepreneurial Practice Review 2(2), 31-35.

[53]. Thornton, P. H. (1999). The sociology of entrepreneurship. Annual Review of Sociology, 25, 19-46. Retrieved from www.annualreview.org/doi/10.1146/

[54]. UNDP (2006). World development report. Retrieved from www.nationmaster.com/graph/eco hum dev ind

[55]. Wilken, P. (1979). Entrepreneurship: A comparative and historical study. Norwood, NJ: Ablex.

[56]. YouWIN (2013). Youth enterprise with innovation in Nigeria. Retrieved from http://www.youwin.org.ng

[57]. Yusuf, I. A. (2011). Rising gross domestic product, rising poverty. Retrieved from www.nationonlineng.net/2011/index.php/business/38561

\section{About the Author}

Dr. Idam, Linus Egwu is an Adjunct Senior Lecturer in the Department of Accountancy/Business Administration and Entrepreneurial Studies, Federal University, Ndufu-Alike Ikwo, Nigeria. He obtained his BSc. (Second Class Upper Division) in Economics from the University of Ibadan in 1977. He got his MBA in Management from the University of Nigeria, Nsukka in 1987 and PhD in Management from Ebonyi State University in 2007. He is a Fellow of the Nigerian Institute of Management (Chartered) and the Pioneer Chairman of Ebonyi State Chapter of the Institute.

Dr. Idam, a former Senior Manager of United Bank for Africa Plc, was the founding Head of the Department of Banking and Finance, Ebonyi State University and a former Dean, Faculty of Management Sciences, Ebonyi State University, Abakaliki, Nigeria. He is currently serving Ebonyi State Government as a Commissioner in the State Fiscal Responsibility Commission. 